\section{DE DE GRUYTER OPEN}

Przedsiębiorczość i Zarządzanie Entrepreneurship and Management University od Social Sciences Publishing House

ISSN 1733-2486

Volume XVI, Issue 2, pp. 121-132

DOI 10.1515/eam-2015-0021

Danuta Janczewska

University of Social Sciences

\title{
Marketing and Logistics Management as an Innovative Direction of Management in the SMEs Sector
}

\begin{abstract}
Marketing and logistics management is now becoming an interesting concept for entrepreneurs, and thus perpetuates the belief that the skills of marketing and logistics of the company contributes to the improvement of the company's competitive position in the market. The activity of businesses from the SME sector is based on a much more modest material resources than it is in large enterprises, thus building logistic and marketing advantages through innovation strategies is often the right direction of improving the competitiveness of the SME sector. The aim of the paper is to present the areas and potential use of new methods of management, with the application of integration of marketing management and logistics processes. Knowledge of the characteristics of both types of processes in the SME sector becomes necessary. Insufficient knowledge of marketing and logistics in SMEs, both in the field of logistics and marketing should be complemented by the development of educational offer by institutions of science.
\end{abstract}

Key words: SME sector, marketing and logistics management, innovation strategies.

\section{Introduction}

Interdisciplinary marketing and logistics approach to management of a SMEs business can become an interesting approach from the entrepreneurs' perspective, and thus the added effect of the application of this method is to improve the marketing and logistics skills. Interdisciplinary perception of phenomena and processes in the company contributes to the growth of knowledge about 
the processes in the company and allows a broader look at the changes in the environment. Logistics is an organizational function which shares responsibilities with Marketing and Production. Companies were traditionally organised according to two main areas: Production and Marketing, considering the rest as auxiliary or support functions [Gimenez, Ventura 2003, p 20]. The foundation of the activity of SMEs sector businesses is a much lower level of material resources than it is in large enterprises, thus building the intangible resources by improving logistics and marketing skills often means investing in enhancing the competitiveness of SME companies. The consequence of the adoption of market orientation by SMEs is the desire to make broad innovation in all areas of the company, in the spirit of the maximum satisfaction of the needs of buyers.

The aim of this article is presentation of the significance and place of innovation in the marketing and logistics management of the company in the development of SME sector. Marketing and logistics management model as an innovation in the management of the SME company and conditions of implementation of this method of management will be presented on the example of study of SMEs businesses in the confectionery industry. There was formulated hypothesis that in SMEs is necessary to integrate both an area for better observation of the market and recognizing the expectation of clients. In the article the observations of $30 \mathrm{SMEs}$ are presented, the group was not representative and conclusion can be confirmed only to researched group.

\section{Marketing and logistics management as an innovation in the SMEs sector}

The introduction of the extended definition of innovation according to the Oslo Manual [Oslo Manual, 2005] gives the opportunity to make changes of the statistical data in relation to SMEs enterprises, introducing innovations based on improvements and changes of products and processes of imitative character. Contemporary typology of innovation distinguishes the new division of innovation, according to specific criteria from the Oslo Manual; these are innovations related to: product, process, organization, marketing [OECD, 2010 , p.5]. In the 2008 edition of statistical surveys of innovation the Central Statistical Office introduced the existing data on technological innovation (product and process), also non-technological innovations (marketing and organizational). Non-technological innovations, until recently, were not considered as important as product and process innovations. In recent years, they have been included in the research of innovation of businesses and they are gaining importance in the companies themselves. The associations with non-technological innovation with strategic decisions, such as decisions on 
technology investments e.g. the purchase of technology or new machinery or equipment, have also been noted. Marketing innovations are related to the implementation of a new marketing method that involves significant changes in the design/construction of a product or in packaging, distribution, promotion or pricing strategy [Oslo Manual 2005, p. 49]. The objective of the implementation is to meet the needs of customers in a better way, open new markets and new product positioning in the market to increase sales. Organisational innovations mean the implementation of a new organizational method in the firm's business practices, workplace organization or relations with the environment. They are implemented in order to e.g. achieve better results by reducing administrative costs or transaction costs, raising the level of job satisfaction, access to assets that are not traded (such as non-codified external knowledge) or reducing the cost of supplies.

The most important logistics processes in SMEs enterprise include the following activities: the supply of products and materials, parts, components and assemblies, forecasting demand and purchasing policy, the flow of information, marketing processes, management and control of resources, distribution - order processing, transport organization, handling of complaints, storage, waste management, financial management.

These processes are of much more modest size and scope than in large companies, nevertheless for the owner of a micro-business they are extremely important from the point of view of their preparation, course and effects. Therefore, contemporary companies are building management methods to integrate many aspects of business. It is already a well-known issue of marketing mix, currently the concept of marketing and logistics management and logistics-mix instruments, combining logistics with lean-management and reengineering are discussed. Each of these concepts requires an individual approach and adjusting management methods to the characteristics of the business.

The superior feature that characterizes the contemporary SMEs business is to provide value to customers. Customer requirements are becoming more and more diverse, as the awareness of the importance of quality is constantly increasing, and expectations of customers are inevitably growing. In particular, it is a necessity of orientation to time and quality management, and the formation of a growing number of interrelations. Marketing and logistics management principles can be formulated on the basis of the theory of the "right bundle of values [Dytwald 1997, pp. 49-54]. This theory defines three variants of delivering value to customers:

- Operational Excellence variant - expressed in offering the customers products and services at the most attractive price. It is shaped by the 
optimization of processes from the point of view of costs, time, flexibility, efficiency, customer comfort and developing effective course of processes,

- Product Leadership variant - depending on innovations, designing new products and their introduction to the market, developing new organizational structures based on processes,

- Customer Intimacy variant, adjusting to the needs of an individual customer - expressed through finding the needs of the customer and his chain of values and building long-lasting relations with him.

The theory of the right bundle of values formulated by M. Treacy and F. Wiersema [Treacy, Wiersema 1995] indicates the integration of logistics and marketing processes in the enterprise. Developing new product concepts, building long-term relationships with customers and adjusting logistics processes of material and information flows confirm the need for simultaneous use of the instruments of marketing and logistics. At the same time innovations are presented as the basis for the implementation of marketing and logistics activities. Szymura-Tyc complements the theory with the concept of building marketing assets - building the competitive advantage of the company. Marketing assets consist of: outstanding products, favourable price, brand identity, links in the distribution channels, the reputation and image of the company [Szymura-Tyc 2001]. Considerations may be supplemented by a model of integration of marketing assets with logistics assets, which include: the unique ability to create logistics processes, the dynamics of processes, flexibility of components of logistics processes and the effectiveness and efficiency of logistics processes - affecting the attractiveness of logistics for the customer.

\section{Innovative process in SMEs business}

According to Schumpeter's theory, innovations are born as a result of scientific research, leading to the transformation of knowledge into material form. Schumpeter identified innovation primarily with the introduction of new products to the production or improving the existing ones, the introduction of new or improved production methods [Schumpeter 1960, p. 322]. He expanded the concept of innovation to other activities of enterprises, such as the opening of a new market, application of a new method of sale or purchase, the use of new raw materials or semi-finished products, the introduction of a new organization of production. It should be emphasized that Schumpeter's theories assumed that the main innovators are large enterprises - hence called "innovators" while he included SME companies to the group of "imitators". Schumpeter's views are not currently justified in economic practice [Stawasz, 
1999 , p. 50] and, according to contemporary researchers small and medium-sized enterprises more responsive to signals from the environment and changing needs of customers. They can therefore act more flexibly, innovate faster and shorten the time of their implementation and commercialization [Nowacki, Staniewski 2010, p. 16].

In Poland studies of innovation of businesses are conducted by the Central Statistical Office and the results are published in "Innovative activities of enterprises" and "Science and Technology" publications. The studies of the CSO do not show a cross-section of the whole sector because they do not distinguish micro-enterprises ${ }^{1}$, providing statistical data for companies employing at least 10 people [Juchniewicz, Grzybowska 2010, p. 34]. Only since 2009, surveys on innovation have also been directed to microbusinesses. The CSO research results indicate low innovativeness of enterprises in Poland. The report of the European Commission also shows that the level of Summary Innovation Index in Poland is less than the average in all the countries of the European Union. Poland was included in the catching-up countries. According to European researchers this level of innovation in Poland is due to the country's low expenditures on R\&D [European Innovation Scoreboard, 2006]. The research conducted by Borkowski [Borkowski 2011, p. 43] indicates that SME enterprises are willing to use EU funds conducting innovation-related activities within the Innovative Economy programme. However, the financial support is not sufficient to create a professional R\&D departments in those companies or using the services of institutions, such as universities, scientific and research centres, consulting companies and specialists - experts. Borkowski indicates that the most commonly implemented innovation in SMEs were:

- product innovations (27\%) - new product or service, image change of existing products,

- process innovations (37\%) - new or improved technological processes,

- organizational innovations (10\%) - new software, new methods for development of staff competences,

- marketing innovations (18\%) - change of the image of products,

- ecological innovations - environmental protection, ecological policy $(15 \%)$.

Research by Wojnicka [Wojnicka 2011] indicates that those companies which conduct focused and coherent strategy in the field of innovation, they have a better chance of success in obtaining and maintaining competitive advantage. According L. Białoń and D. Janczewska examination and assessment

${ }^{1}$ This situation may be due to methodology, different from the applied in EU countries. 
of the factors allowing the creation of innovative ideas in order to their realization, implementation and commercialization is the fundamental problem while developing a strategy of innovation [Białoń, Janczewska 2009]. Indeed, the preparation of such a diagnosis in the SMEs company can be difficult, due to insufficient knowledge about the essence of innovation and innovation process $^{2}$. In one owner's company, as well as in its competitor's business, the characteristics of the sources of innovation and methods of forecasting future events are important in order to formulate steps of innovation strategy.

\section{Authors' study of confectionery sector}

Confectionery branch in Poland includes more than 1000 companies, of which only 10 belong to the group of large enterprises, while the others can be classified as micro, small and medium-enterprises. The study was conducted in 30 SMEs enterprises from the confectionery industry, of which $20 \%$ account for micro-enterprises, $50 \%$ - small firms and 30\% of medium-sized companies. Companies were located in the following state voivodships: KuyavianPomeranian, Lodz, Mazovian, and Lesser-Poland.

The aim of researches was description of connecting the marketing instruments and logistic methods in management of enterprise. There was formulated a hypothesis that in SMEs it is necessary to integrate both of area for reaching the better observation of the market and recognizing the expectation of clients.

Surveyed SMEs companies from the confectionery industry declared their own market strategies as strategies based on building relationships with customers, on improving marketing processes or processes related to the improvement of work organization. At the same time they pointed to barriers in the form of external instruments for innovation support system of this type such as available credit, access to knowledge and expert advice. The author's own research conducted among SMEs enterprises in the confectionery industry showed a growing interest in non-technological innovation of SMEs enterprises, such as organizational and marketing innovation. In the surveyed SMEs enterprises from the confectionery industry there have been manifestations of marketing and logistics management based on a combination of marketing

${ }^{2}$ During discussions in the SME businesses of confectionery sector, the owners claimed that innovations do not exist in their companies, treating the concept of „innovation' as a new product or a breakthrough invention. After the analysis of changes implemented in their businesses there have been identified a number of innovations: product, marketing and ecological innovations in the area of confectionery production. Also, numerous organizational changes were implemented as well as independently designed innovative systems of information flow. 
activities with logistics system of the company. The analysis of the logistics aspect of the formulation of marketing and logistics management in the studied confectionery companies led to the identification of process steps for its implementation.

These steps can be presented as follows:

- Step I. Gathering the necessary marketing knowledge to determine the market position of the company and its resources as well as the knowledge about the environment.

- Step II. Accumulation of logistics knowledge including definition of logistics processes in SMEs and creating a system of communication with buyers.

- $\quad$ Step III. Formulating marketing offer and logistics offer - by matching the company's resources to customers expectations.

- Step IV. Developing marketing and logistics strategy through the choice of methods and means of achieving an integrated strategy based on the marketing and logistics analysis as well as the definition of supplementary activities in the area of marketing and logistics.

- Step V. Monitoring the implementation of marketing and logistics process of SME business management through the selection and periodic assessment of the performance indicators of the same process.

The share of SMEs companies applying marketing and logistics management as a management method was $30 \%$, which means that other surveyed SMEs did not perceive benefits arising as a result of the application of integrated management. In companies which did not apply the marketing and logistics management system, the definition of logistics-marketing system was related to barriers of lack of knowledge about marketing and logistics. The purpose of organizational innovation was primarily to achieve better financial results, higher efficiency, better use of human resources and intellectual capital of SMEs. Marketing innovations included the implementation of new marketing methods related to marketing-mix.

Especially in the area of promotion (i.e. marketing information) SMEs businesses introduced wider marketing at fairs, online advertising and other forms of promotion. With respect to forms of product innovation, the innovations have occurred as a complete redesign of the product in terms of its structure, construction, and use. The SMEs surveyed pointed to the introduction of new types of packaging, more convenient for the buyers, or consistent with the requirements of quality and environmental standards. Innovations in promotion were related to the introduction of new methods and forms of promotion of new products or promotion of the company as a whole. 
Understanding the relationship between the SMEs enterprise and other market elements allows the identification of barriers in achieving SMEs success in the market and matching logistics strategies and innovation to market needs. One of the aspects of marketing analysis of determinants of innovative activity is gathering information on the types of innovation already implemented in the relevant market and the effects of innovation brought about after its implementation - both tangible and intangible (hard effects - soft effects). Marketing support of logistics processes in the company is shown in Table 1.

\section{Table 1. Marketing support of logistics processes}

\begin{tabular}{|c|c|c|}
\hline $\begin{array}{l}\text { Basic logistics } \\
\text { processes }\end{array}$ & $\begin{array}{c}\text { Characteristic features of } \\
\text { a SME enterprise }\end{array}$ & $\begin{array}{l}\text { Marketing support of the } \\
\text { process }\end{array}$ \\
\hline 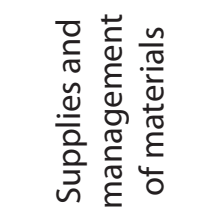 & $\begin{array}{l}\text { Processes run intermittently, } \\
\text { free - dependent on the } \\
\text { level of financial resources. } \\
\text { Contracts for raw pastry } \\
\text { relate to smaller quantities. }\end{array}$ & $\begin{array}{l}\text { Starting the process and its } \\
\text { course are dependent on } \\
\text { market research and customer } \\
\text { expectations. }\end{array}$ \\
\hline 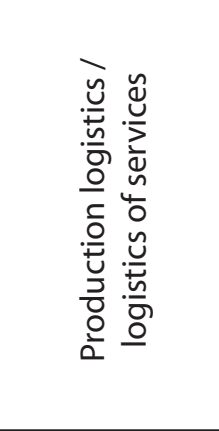 & $\begin{array}{c}\text { Confectionery } \\
\text { manufacturing processes } \\
\text { implemented using } \\
\text { manual labour, lack of } \\
\text { automation, often lack of the } \\
\text { implementation of quality } \\
\text { management systems. } \\
\text { Process infrastructure } \\
\text { adjusted to the financial } \\
\text { capacity of the entrepreneur. }\end{array}$ & $\begin{array}{l}\text { Adjusting the volume of } \\
\text { production and its type to } \\
\text { market expectations and offer } \\
\text { of competitive companies. }\end{array}$ \\
\hline 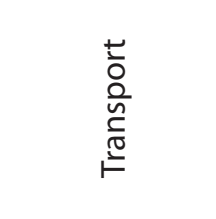 & $\begin{array}{l}\text { The company focused on } \\
\text { minimizing costs, transport } \\
\text { processes carried out by its } \\
\text { own means of transport. }\end{array}$ & $\begin{array}{l}\text { Marketing analysis and } \\
\text { customer segmentation to } \\
\text { optimize transport routes and } \\
\text { the correct choice of means of } \\
\text { transport and prices. }\end{array}$ \\
\hline 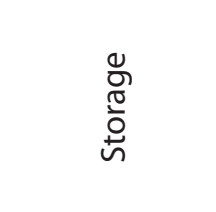 & $\begin{array}{l}\text { Warehouse processes carried } \\
\text { out by hand, minimal use of } \\
\text { machinery and equipment, } \\
\text { including computers. }\end{array}$ & $\begin{array}{l}\text { Quantitative parameters of the } \\
\text { flow of goods in the warehouse } \\
\text { are adjusted to the needs of } \\
\text { the market. Marketing analyses } \\
\text { determine the size of demand. }\end{array}$ \\
\hline
\end{tabular}




\begin{tabular}{|c|c|c|}
\hline 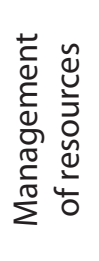 & $\begin{array}{l}\text { Control and replenishment is } \\
\text { carried out using traditional } \\
\text { methods, computers are } \\
\text { used occasionally, lack of } \\
\text { specialized programs to help } \\
\text { manage inventory. }\end{array}$ & $\begin{array}{l}\text { Changes in the level of } \\
\text { inventories arising from the } \\
\text { needs of the market and } \\
\text { customer structure. }\end{array}$ \\
\hline 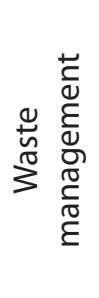 & $\begin{array}{l}\text { Environmental management } \\
\text { is not implemented in the } \\
\text { systematic way, the activities } \\
\text { in the context of reverse } \\
\text { logistics are implemented } \\
\text { sporadically; lack of interest } \\
\text { in waste management. }\end{array}$ & $\begin{array}{l}\text { The study of environment } \\
\text { enables marketing planning, } \\
\text { taking into account the } \\
\text { applicable environmental } \\
\text { regulations. }\end{array}$ \\
\hline
\end{tabular}

Source: author's own study on the basis of D. Janczewska (2012), Zarzadzanie dziataniami marketingowymi w mikroprzedsiębiorstwach [w:] Ekonomiczno-prawne aspekty prowadzenia dziatalności gospodarczej w Polsce [red.:] A. Cheda, Wyd. Fundacja Ius Medicinae, Warszawa, p. 128-129.

The subjects of the diagnosis were: marketing and logistics potential of companies [Janczewska 2014, p. 155], management of the company, and its framework of innovation management. The success of the implementation of innovative management practices is the effect of the climate for innovation in the company and incentive system for the employees - participants of the innovation process, the competence of managers and employees as well as the way in which the company conducts marketing innovation. Based on the examination of management of logistics and marketing processes in the surveyed confectionery enterprises the following model of action has been proposed, which has been used, among other things in the contract with a large retail chain - as shown in Fig. 2. 


\section{Fig.2. Innovation management procedure in logistics and marketing process of creating value for the customer}

1. IDENTIFICATION OF MARKETING AND LOGISTICS POTENTIAL OF THE COMPANY: Analysis of the activity, market, competitive environment, market segmentation, Analysis of competitors.

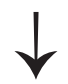

2. MARKET OFFER: PRODUCT / SERVICE - marketing instruments of the company 5P:

(marketing-mix): Product, Price, Promotion - advertising, Place, People

3. LOGISTICS OFFER - defining sources of supply, defining production process, defining means storage means, selection of distribution channels, defining delivery time and means of transport, choice of formal documents (contracts, conditions), customer relations.

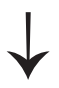

4. Identification of key values PRODUCT/SERVICE for the customer : Research of customers (questionnaire, analysis, conclusions), business reaction towards customer expectations, defining key values.

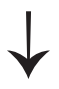

5. Elements of marketing and logistics strategy accounting for creating value for the customer:

Final concept of the product - based on the value for the customer.

Source: author's own study. 
It should also be remembered that the important role (and perhaps even decisive for the success of implementation of innovations) - is the person of the entrepreneur. These and other elements of management must also be diagnosed under the conditions of innovation. The typology of innovation alone can contribute to the selection of the best innovative activity for the SME company.

\section{Summary}

Article presented observations of integration of marketing instruments and logistic methods in managing of SMEs in confectionery branch. The hypothesis was confirmed that integration of the marketing and logistic is necessary to growth of competitiveness of SMEs. Identification of both areas: marketing and logistic give possibilities to benefit from the implementation of marketing and logistics management as an innovation in the management of the SME company requires broad knowledge and collection of data about the possible use of innovation in the enterprise. Innovation strategy formulation - is associated with the logistics of supply and distribution, by gathering information about the environment, activities of competitive businesses. It becomes necessary to raise the level of education of modern managers through participation in training and postgraduate studies both in the field of logistics and marketing.

\section{References}

Białoń L., Janczewska D. (2009), Uwarunkowania strategii innowacji w organizacjach, „Postępy Techniki Przetwórstwa Spożywczego”, Nr 1, Tom 19/34, ss. 116122, Wyd. Wyższa Szkoła Menedżerska, Warszawa.

Dytwald J. (1997), Współczesne koncepcje zarządzania korporacjami, WSPiZ, Warszawa, ss. 49-54 .

Bławat F. (2003) Przedsiębiorca w teorii przedsiębiorczości i praktyce matych firm, Wyd. Gdańskie Towarzystwo Naukowe, Gdańsk.

Christopher M. (2011), Logistic \& Supply Chain Management, Fourth edition, Pearson Education Limited, GB.

Collins J.C. ( 2003), Od dobrego do wielkiego, czynniki trwatego rozwoju i zwycięstwa firm, Wyd. SPM Projekt, Wrocław.

European Innovation Scoreboard Comparative Analysis Innovation Performance (2006), http://www.proinno-europe.eu/doc/EIS (31.10.2012).

Freytag A., Thurik A. (edit.) (2009), Entrepreneurship and culture, Springer, Lund. 
Gimenez C., Ventura E. (2003), Logistics - Production, Logistics-Marketing And External Integration: Their Impact On Performance, GREL-IET; Universitat Pompeu Fabra, Spain.

GUS (2010), Dziatalność innowacyjna przedsiębiorstw w latach 2006-2009, Wyd. Główny Urząd Statystyczny, Warszawa.

Janczewska D. (2011), Wptyw zarządzania marketingowo-logistycznego na poziom luki technologicznej w przedsiębiorstwach z grupy MSP, ss. 81-95, „Przedsiębiorczość i Zarządzanie”, Tom XII, zeszyt 9, Wyd. SWSPiZ, Łódź.

Janczewska D. (2012), Znaczenie logistycznej obstugi klienta dla rozwoju firm rodzinnych $w$ sektorze mikroprzedsiębiorstw [in:] Firmy rodzinne - wspótczesne wyzwania przedsiębiorczości rodzinnej. Determinanty rozwoju (red.) A. Marjański, „Przedsiębiorczość i Zarządzanie”, Tom XIII, Zeszyt 8, Społeczna Akademia Nauk w Łodzi, Łódź, pp. 311-324.

Janczewska D. (2012 b), Zarzadzanie dziataniami marketingowymi w mikroprzedsiębiorstwach, [in:] Ekonomiczno-prawne aspekty prowadzenia dziatalności gospodarczej $w$ Polsce, [ed.] A. Cheda, Wyd. Fundacja Ius Medicinae, Warszawa.

Juchniewicz M., Grzybowska B. (2010), Innowacyjność mikroprzedsiębiorstw $w$ Polsce, Wyd. PARP, Warszawa.

Kokocińska M. (2012), Mate i średnie przedsiębiorstwa w gospodarkach europejskich, Wyd. Uniwersytetu Ekonomicznego w Poznaniu, Poznań.

Korpysa J. (2012), Uwarunkowania przedsiębiorczości indywidualnej przedsiębiorstw typu start-up [in:] Studia ekonomiczne regionu tódzkiego. Wybrane aspekty zarzadzania nowoczesna organizacja, Nr VIII, Wyd. PTE Oddział w Łodzi.

Nowacki R., Staniewski M.W. (2010), Podejście innowacyjne w zarządzaniu przedsiębiorstwem, Difin, Warszawa.

OECD (2010), The OECD Innovation Strategy. Getting a head start on tomorrow, Paris.

Schumpeter J. (1960), Teoria rozwoju gospodarczego, PWN, Warszawa.

Stawasz E. (1999), Innowacje a mata firma, Wydawnictwo Uniwersytetu Łódzkiego, Łódź.

Szymura-Tyc M. (2001), Nowe paradygmaty konkurencji i marketingu a budowa przewagi konkurencyjnej przedsiębiorstw na rynku europejskim, „Organizacja i Kierowanie", $\mathrm{Nr} 1$.

Szymura-Tyc M., Zarzadzanie przez wartość dla klienta - budowa wartości firmy. http://www.zti.com.pl/instytut/pp/referaty/ref4_full.html (20.10.2012).

Treacy M., Wiersema F. (1995), The Discipline of Market Leaders, Addison-Wesley, London. 